ELORE (ISSN 1456-3010), vol. 19 - 1/2012.

Julkaisija: Suomen Kansantietouden Tutkijain Seura ry.

[http://www.elore.fi/arkisto/1_12/fingerroos.pdf]

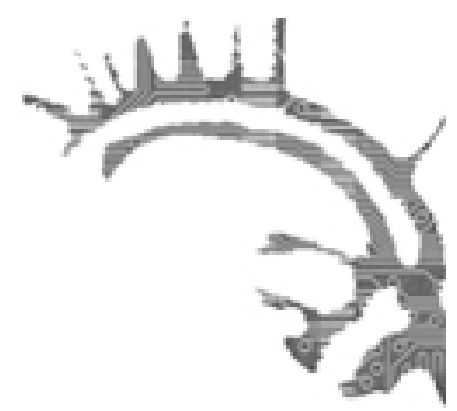

\title{
SAATTEEKSI
}

\section{IDÄSTÄ TULLEET VIERAAT KERRONNASSA, MUISTELUSSA JA MAISEMASSA}

\section{Outi Fingerroos}

Tämän teemanumeron taustalla on sekä Suomen Akatemian rahoittama tutkimushanke Vieraita idästä (engl. Strangers from the East - Narratives of Karelian Exiles and Re-immigrants from Russia Regarding their Integration in Finland) että ajatus siitä, että toisen maailmansodan jälkeen idästä Suomeen suuntautuvaa muuttoliikettä on tapahtunut nimikkeillä siirtolaisuus, maahanmuutto, paluumuutto ja siirtokarjalaisuus.

Siirtolainen määritellään Suomessa tavallisimmin henkilöksi, joka on muuttanut pysyvästi toiseen maahan riippumatta siitä, onko hän maahan- vai maastamuuttaja (näin kirjoitti jo Korkiasaari 1992, 4-5). Yleistä ja kansainvälisesti jaettua käsitystä siirtolaisuudesta ei ole kuitenkaan olemassa. IOM - International Organization of Migration esimerkiksi määrittää, että

termiä siirtolainen käytetään yleensä kuvaamaan henkilöä, joka tekee omaehtoisen päätöksen toiseen maahan muuttamisesta, usein aineellisten tai sosiaalisten edellytysten kohentamiseksi ja omien tai perheen tulevaisuudennäkyminen parantamiseksi. Ihmiset muuttavat myös monista muista syistä. (IOM / Mitä siirtolaisuus on? [online].)

Suomalaisessa akateemisessa tutkimuksessa siirtolaisuus erotetaan nykyään kuitenkin laajemmasta käsitteestä maahanmuutto. Siirtolaisuudella viitataan ensi sijassa työperäiseen maahanmuuttoon. (Martikainen, Sintonen \& Pitkänen 2006, 25.) 
Siirtolaisuus ja maahanmuutto ovat molemmat transnationaalin (Vertovec 2009) eli ylirajaisen (Hautaniemi 2004) liikkuvuuden ilmenemismuotoja. Ne kuvaavat sitä globaalia, kansallisvaltioiden rajat ylittävää muuttoa, jonka syyt ovat moninaisia, mutta aina sidoksissa paikallisyhteisön elämäntapaan ja -mahdollisuuksiin.

Venäjänkielisiä ihmisiä asui Suomessa vuoden 2011 lopussa tilastojen mukaan 58 331 henkilöä. He ovat Suomen suurin maahanmuuttajaryhmä. (SVT, Väestörakenne [online].) Suomalaisessa poliittisessa kulttuurissa hallitsemattomaksi leimattu maahanmuutto ja pakolaisongelma ovat olleet 1990-luvun alusta asti kriittisen keskustelun ja pelon aihioita. Maahanmuutto on etenkin populistisessa puheessa stigmatisoitu ilmiö (ks. myös Apo 1998) ja multikulturalismi on vain sattumanvaraisesti osa suomalaisuutta.

Vieraita idästä -hankkeessa post doc -tutkijana työskentelevä jyväskyläläinen etnologi Tiina-Riitta Lappi on paneutunut Venäjältä Jyväskylään muuttaneiden maahanmuuttajien kerrontaan erityisesti kaupunkitilan haltuunoton näkökulmasta. Hänen artikkelinsa ei ennättänyt valmistua tähän Eloren teemanumeroon, mutta teksti ilmestyy syksyn 2012 numerossa täydentäen käsillä olevaa kokonaisuutta taustaltaan ei-suomalaisten idäntulijoiden osalta. Hänen artikkelinsa tulee todentamaan sitä, miten Suomessa yhteiskunnan uudet jäsenet rajataan käytännössä symbolisen suomalaisuuden ulkopuolelle mm. kielensä, alkuperänsä ja kulttuurinsa vuoksi. Maahanmuuttajat ja etnisten vähemmistöjen edustajat kärsivät ikuisesta suomalaisuusvajeesta, kuten tutkija Annika Forsander (2002) on todennut.

Suomessa paluumuuttajaksi määritellään ulkomailta Suomeen muuttava henkilö, ulkosuomalainen, joka palaa juurilleen pidemmän tai lyhyemmän ulkomailla vietetyn ajan jälkeen. Suomessa käsitettä sovelletaan entisiin ja nykyisiin Suomen kansalaisiin ja entisen Neuvostoliiton alueelta peräisin oleviin henkilöihin, joilla on suomalainen syntyperä. Suomessa paluumuuttajien erityisryhmän - kaikkiaan noin 30000 henkilöä - muodostavat inkerinsuomalaiset paluumuuttajat. Heidän paluumuuttonsa, joka alkoi vuonna 1990, on juuri tyrehtymässä, kuten porilainen kulttuuriperinnöntutkija, tohtorikoulutettava Minna-Liisa Salonsaari taustoittaa artikkelissaan "Kerrottu ja muisteltu inkerinsuomalaisten paluumuutto". Salonsaari myös muistuttaa, että inkeriläisten paluumuutto voidaan nähdä jatkumona vuosisataiselle muuttoliikkeiden virralle, joka alkoi viimeistään Stolbovan rauhasta vuonna 1617. Silloin Ruotsi sai väliaikaisesti Inkerin haltuunsa ja joukko savakkoja ja äyrämöisiä muutti Inkerinmaalle. Suurimman suomalaistaustaisten siirtolaisten ryhmän Venäjällä muodostavatkin Inkeriin muuttaneiden jälkeläiset eli inkerinsuomalaiset.

Käsite siirtokarjalainen, kuten synonyymi evakko, ja ilmaisut luovutettu ja menetetty Karjala syntyivät toista maailmansotaa seuranneella jälleenrakennuskaudella (1940-1952). Käsitteen vakiintumiseen vaikutti erityisesti kuitenkin Pariisin rauhansopimus (10.2.1947), joka sinetöi noin 407000 sïrtokarjalaisen muuton Suomeen. Heidän lisäkseen uuden itärajan taakse siirtyi noin 23000 evakkoa Petsamosta, Sallasta ja Kuusamosta. Taustaltaan ja kansalaisuudeltaan suomalaisten evakkojen muistelukerrontaan kokoelmassa paneutuvat Heli Kananen, Kirsi Niukko ja Ulla Savolainen. Näkökulmina ovat siirtokarjalaisten integraatio, maisema ja rakennettu kulttuuriperintö sekä kerronnan keinot. 


\section{Outi Fingerroos: Idästä tulleet vieraat kerronnassa, muistelussa ja maisemassa}

Vieraita idästä -hankkeen alkuperäiset tutkimuskysymykset olivat: Kuinka vieraalle maalle muuttavan henkilön kansalaisuus vaikuttaa kohteluun uusilla asuinsijoilla? Millaisia näkökulmia kerronnallinen tieto siirtolaisuudesta ja maahanmuuttajuudesta tarjoaa virallisen tiedon rinnalle? Teemanumeron neljä artikkelia vastaavat näihin kysymyksiin kerronnallisesta näkökulmasta. Artikkeleissa pohditaan, millaisena maahanmuutto, siirtokarjalaisuus, maassamuutto ja maastamuutto näyttäytyvät, kun tarkastelun painopiste on selkeästi mikrotasolla: ihmisten kerronnassa, muistissa ja maiseman tulkinnoissa.

Kerronta ja muisti ovat kokoelman artikkeleissa toista tietoa (ks. Hänninen, Karjalainen \& Lahti 2005, 3-6; Fingerroos \& Haanpää 2009, 135-136; Fingerroos \& Peltonen 2006,11-13). Tämä toinen tieto avaa konkreettisia näkökulmia vieraalle maalle muuttaneiden väestöryhmien sopeutumisen kysymyksiin. Minna-Liisa Salonsaaren sanoin kaikki kerrottu, kuvattu ja esitetty on vaikuttanut niihin määrittelytapoihin, joilla muuttajat itse ja toiset heitä määrittelevät.

Vieraita idästä -hankkeen tehtävänä on ollut tuottaa kokemuskerrontaan ja muistiin liittyvän analyysin avulla konkreettisista tietoa ylirajaisuuteen liittyvistä sopeutumisen kysymyksistä. Suoraan näihin kysymyksiin vastaavat artikkeleissaan Vieraita idästä -hankeen tutkijat Minna Liisa-Salonsaari, Heli Kananen ja Kirsi Niukko. Salonsaaren artikkelissa inkerinsuomalaiset naiset Elsa ja Anna saavat äänen: he ovat kahteen eri sukupolveen kuuluvia naisia ja kertovat sopeutumiskertomuksensa. Kirjoittaja todentaa, että erilaiset sukupolvet ja erilaiset elämänkokemukset tuottavat erilaisia kertomuksia ja paluumuutto limittyy kertomuksissa henkilökohtaisiin elämänvaiheisiin. Hän kirjoittaa: "Henkilökohtaisuudessaan nämä paluumuuttajien kertomukset tuovat esiin sen, että on olemassa erilaisia paluumuuttoja, erilaisia paluumuuttokokemuksia sekä erilaisia tapoja kertoa paluumuutosta ja sen kokemisesta."

Raja-Karjalassa asui ennen toista maailmansotaa noin 38000 suomalaista ortodoksia, joiden kieli ja uskonto poikkesivat muista siirtokarjalaisista evakoista. Uusilla asuinsijoilla ortodoksievakot joutuivat alkuperäisväestön "silmätikuiksi": heitä halveksuttiin sekä nimiteltiin ja toisinaan he kohtasivat jopa rasismia. Heli Kananen erittelee artikkelissaan, millä tavoin suomalaisen kantaväestön harjoittama sosiaalinen kontrolli toimi ortodoksisen siirtoväen sopeuttamisen välineenä Pohjois-Savossa. Kananen hyödyntää myös rasismintutkimuksesta tuttua vastapuheen käsitettä, jonka avulla hän analysoi niitä tapoja, joita ennakkoluulojen kohteeksi joutuneet ortodoksit käyttivät torjuakseen itseensä kohdistettua syrjintää. Artikkeli todentaa, että suomalainenkin siirtokarjalaisväestö törmäsi sijoitusalueilla samoihin syrjimisen käytänteisiin, mihin siirtolaiset ja maahanmuuttajat ovat törmänneet kaikkialla maailmassa. Vastapuhe oli tässä tilanteessa idäntulijoiden käyttämä keino mitätöidä savolaisten harjoittamia syrjiviä kontrollitekoja. Kerronta oli heille keino suojata identiteettiään ja ortodoksista omakuvaansa.

Maisemantutkijan ja tohtorikoulutettavan Kirsi Niukon artikkeli "Pinomäen ajat - rakennettu ympäristö" asukkaiden kertomana avaa sopeutumisen kysymykseen kiinnostavan näkökulman. Tarkasteltavana on Porin Pinomäen ruotsalaistaloalue, joka rakennettiin niin kutsutulla jälleenrakennuskaudella. Niukko teki Pinomäessä rakennetun ympäristön kenttätutkimusta ja huomasi, että alueen asukkaat kertovat inventoinnin yhteydessä mielellään myös omasta elämästään ja sopeutumisestaan. 


\section{Outi Fingerroos: Idästä tulleet vieraat kerronnassa, muistelussa ja maisemassa}

Niukon mukaan rakennusinventointiin liittyvää vuorovaikutusta voi pitää temaattisesti ohjattuna muistelukerrontana: "Asukas harvoin kykenee muistamaan rakennuksiin liittyviä muutoksia ja korjaustoimenpiteitä linkittämättä niitä osaksi elämäntarinaansa. Asukkaat siis kertovat tutkijalle arjen kokemusmaailmastaan arkikerronnan keinoin.”

Vieraita idästä -hankkeen tutkijoiden kirjoituksia täydentää helsinkiläisen folkloristin Ulla Savolaisen artikkeli "Lapsuuden evakkomatkan monet merkitykset - kerrontastrategiat kirjoitetussa muistelukerronnassa". Artikkelin aiheena ovat lapsena evakuoitujen siirtokarjalaisten kirjoitetut muistelukertomukset evakkomatkastaan. Evakkokertomuksissaan kirjoittajat käsittelevät itselleen ja yhteisölleen merkityksellisiä menneisyyden tapahtumia. Tekstit ovat erityisiä kokonaisuuksia, joissa yhdistyvät kirjoittajien kerrontastrategioissaan hyödyntämät tyylit, ilmaisut ja genret.

\section{LÄHTEET}

APO, SATU 1998: Suomalaisuuden stigmatisaation traditio. - Pertti Alasuutari \& Petri Ruuska (toim.), Elävänä Euroopassa. Munttuva suomalainen identiteetti. Tampere: Vastapaino.

FINGERROOS, OUTI \& HAANPÄÄ, RIINA 2009: Vieraita idästä. Siirtokarjalaisten ja venäläisten paluumuuttajien kotoutuminen Suomeen. - Ruotsala, Helena \& Saarikoski, Petri \& Santikko, Maija (toim.), Matkalla. Pori: Kulttuurituotannon ja maisemantutkimuksen laitos.

FINGERROOS, OUTI \& PELTONEN, ULLA-MAIJA 2006: Muistitieto ja tutkimus. - Fingerroos, Outi \& Haanpää, Riina \& Heimo, Anne \& Peltonen, UllaMaija (toim.), Muistitietotutkimus. Metodologisia kysymyksiä. Helsinki: Suomalaisen Kirjallisuuden Seura.

FORSANDER, ANNIKA 2002: Luottamuksen ehdot. Maahanmunttajat 1990-luvun suoma- laisilla työmarkkinoilla. Helsinki: Väestöliitto, Väestöntutkimuslaitos.

HAUTANIEMI, PETRI 2004: Pojat! Somalipoikien kiistanalainen nuoruus Suomessa. Helsinki: Nuorisotutkimusverkosto.

HÄNNINEN, SAKARI, KARJALAINEN, JOUKO \& LAHTI, TUUKKA (toim.) 2005: Toinen tieto. Kirjoituksia buono-osaisunden tunnistamisesta. Helsinki: Sosiaali- ja terveysalan tutkimus- ja kehittämiskeskus.

IOM - International Organization of Migration / Mitä sïrtolaisuns on? Avainkäsitteitä [online]. < http://iom.fi/index.php?option=com_content\&view $=$ article\&id $=144$ \&Itemid $=139>$ [12.4.2012.]

KORKIASAARI, JOUNI 1992: Sïrtolaisia ja ulkosuomalaisia. Suomen siirtolaisuns ja ulkosuomalaiset 1980-luvulla. Helsinki: Työministeriö.

SUOMEN VIRALLINEN TILASTO (SVT): Väestörakenne [online]. Helsinki: Tilastokeskus. <http://www.stat.fi/til/vaerak/> [12.4.2012.]

MARTIKAINEN, TUOMAS, SINTONEN, TEPPO \& PITKÄNEN, PIRKKO 2006: Ylirajainen likkuvuus ja etniset vähemmistöt. - Martikainen, Tuomas (toim.), Ylirajainen kultturi. Etnisyys Suomessa 2000-luvulla. Helsinki: SKS.

VERTOVEC, STEVEN 2009: Transnationalism. London \& New York: Routledge. 
Outi Fingerroos: Idästä tulleet vieraat kerronnassa, muistelussa ja maisemassa

Dosentti Outi Fingerroos työskentelee etnologian yliopistotutkijana Jyväskylän yliopistossa. Hän koordinoi myös Jyväskylän yliopiston Monikulttuurisuus ja vuorovaikutus -osaamiskeskuksen toimintaa. Hän toimii vuonna 2012 päättyvän Vieraita idästä -hankkeen johtajana. 